\title{
KONTROL OPTIMAL PENYEBARAN PENYAKIT GONORE DENGAN MENGGUNAKAN PRINSIP MINIMUM PONTRYAGIN
}

\author{
Lovi Dwi Purnamasari, Mariatul Kiftiah, Yudhi
}

\begin{abstract}
INTISARI
Penyakit Gonore adalah salah satu penyakit menular seksual yang disebabkan oleh bakteri Neisseria gonorrhoeae. Penularan penyakit Gonore dapat dikendalikan dengan pemberian antibiotik dan melakukan terapi klinis pada individu yang terinfeksi penyakit Gonore. Pada penelitian ini, model penyebaran penyakit Gonore tipe SI (Susceptible-Infected) dikendalikan dengan pemberian suatu kontrol pengobatan berupa antibiotik (u). Pemberian kontrol berupa antibiotik ini bertujuan untuk meminimumkan jumlah individu yang ada pada subpopulasi terinfeksi. Model matematika SI yang telah diberi kontrol u selanjutnya diselesaikan menggunakan Prinsip Minimum Pontryagin sehingga didapat suatu kontrol optimal u*. Hasil simulasi numerik yang telah dilakukan dengan nilai parameter tingkat pengurangan dan penambahan jumlah individu pria yang terinfeksi, tingkat pengurangan dan penambahan jumlah individu wanita yang terinfeksi, dan konstanta positif untuk menjaga ukuran populasi individu terinfeksi berturut-turut adalah $a_{1}=1, b_{1}=0.006 a_{2}=1, \quad b_{2}=$ $0.004, A_{1}=1$, dan $A_{2}=1$ menunjukkan bahwa pemberian kontrol berupa pengobatan menggunakan antibiotik dapat menekan jumlah individu pada subpopulasi terinfeksi.
\end{abstract}

Kata kunci: gonore, model SI, kontrol optimal, prinsip minimum pontryagin

\section{PENDAHULUAN}

Penyakit menular seksual (PMS) dapat disebabkan oleh virus, bakteri, jamur, serta parasit dan ditularkan saat melakukan hubungan seksual. Selain ditularkan melalui hubungan seksual, PMS juga dapat ditularkan melalui ibu hamil kepada janin dalam kandungan atau saat kelahiran, melalui transfusi darah yang telah tercemar, kadang-kadang dapat ditularkan melalui alat kesehatan [1]. Ada banyak jenis PMS yang menyebar di seluruh dunia, diantaranya adalah HIV/AIDS (Human Immunodeficiency Virus/ Acquired Immunodeficiency Syndrome), herpes genital, kutil kelamin, dan Gonore. Penyakit Gonore disebabkan oleh bakteri Neisseria gonorrhoeae yang menginfeksi lapisan dalam uretra (saluran kencing dan sperma), serviks (leher rahim), tenggorokan, dan bagian putih mata (conjuctiva) [1]. Diperkirakan bahwa tidak kurang dari 25 juta kasus baru penyakit Gonore ditemukan setiap tahun di seluruh dunia dan sekitar 820,000 orang di AS mengalami infeksi Gonore baru setiap tahunnya [2]. Gonore tidak dapat menyebar melalui ciuman, pelukan, berbagi kamar mandi atau handuk, kolam renang, toilet duduk, piring atau gelas, karena bakteri ini tidak bisa bertahan diluar tubuh untuk waktu yang lama. Penyakit ini dapat dicegah dengan cara menggunaan alat kontrasepsi seperti kondom dan disembuhkan dengan melakukan pengobatan dan terapi klinis. Akan tetapi pengobatan tidak menyebabkan individu yang telah terinfeksi kebal terhadap penyakit dikemudian harinya. Tidak ada imunitas bawaan, walaupun bagi orang yang pernah menderita penyakit ini. Juga tidak ada perbedaan mengenai kekebalan antara berbagai suku bangsa, jenis kelamin atau umur [3].

Salah satu pendekatan untuk menjelaskan solusi dari permasalahan penyebaran penyakit menular seksual Gonore yang terjadi dalam dunia nyata adalah menerjemahkan permasalahan tersebut ke dalam model matematika. Suatu model matematika penyebaran penyakit menular dapat dikendalikan dengan pemberian suatu kontrol yaitu pengobatan menggunakan antibiotik. Pemberian kontrol pengobatan ini bertujuan untuk meminimumkan jumlah individu yang terinfeksi penyakit. Penyelesaian kontrol optimal dapat dilakukan dengan beberapa metode, diantaranya adalah Prinsip Minimum Pontryagin [4] dan LQR (Linear Quadratic Regulator)[5]. Prinsip Minimum Pontryagin pertama kali diformulasikan oleh matematikawan asal Rusia yang bernama Lev. Pontryagin pada tahun 1956. Pada prinsipnya, prinsip minimum digunakan untuk memperoleh kontrol terbaik pada sistem dinamik dari state awal hingga state akhir, yaitu dengan mengoptimalkan fungsi objektif $J$ dengan menggunakan kontrol $u$ [6]. Pada Prinsip Minimum Pontryagin, state yang digunakan tidak harus state yang terkontrol dan teramati. Terkontrol dimaksudkan bahwa setiap komponen pada sitem 
state dipengaruhi kontrol dari keadaan awal sampai keadaan akhir. Sedangkan teramati dimaksudkan bahwa setiap state dapat diamati pada keluaran y dari waktu awal sampai ke waktu akhir [5].

Penelitian ini bertujuan membentuk model penyebaran penyakit menular seksual Gonore dengan pemberian variabel kontrol $u$ berupa antibiotik serta mendapatkan nilai kontrol optimal dari permasalahan penyebaran penyakit Gonore dengan menggunakan Prinsip Minimum Pontryagin. Model yang digunakan adalah model endemi SI (Susceptible-Infected) [7].

\section{MODEL ENDEMI SI (SUSCEPTIBLE-INFECTED)}

Proses pembentukan model penyebaran penyakit menular seksual Gonore ini dimulai dengan membagi populasi menjadi dua subpopulasi, yaitu subpopulasi susceptible $(S)$ menyatakan populasi individu yang sehat dan rentan terhadap penyakit dan subpopulasi infected (I) menyatakan populasi individu yang terinfeksi penyakit dan dapat sembuh. Subpopulasi rentan $(S)$ terdiri dari jumlah individu pria yang rentan terhadap penyakit $\left(S_{1}\right)$ dan jumlah individu wanita yang rentan terhadap penyakit $\left(S_{2}\right)$. Sedangkan subpopulasi terinfeksi $(I)$ terdiri dari jumlah individu pria yang terinfeksi penyakit $(X)$ dan jumlah individu wanita yang terinfeksi penyakit $(Y)$. Selanjutnya $S(t)$ untuk menyatakan populasi kelas individu $S$ pada saat $t$, dan $I(t)$ untuk menyatakan populasi kelas individu $I$ pada saat $t$. Berikut beberapa asumsi yang digunakan dalam pembentukan model penyebaran penyakit Gonore, yaitu :

1. Model penyebaran penyakit Gonore dalam penelitian ini berlaku untuk populasi heteroseksual.

2. Populasi memiliki perilaku seragam.

3. Tingkat pengurangan jumlah individu pria yang terinfeksi diperoleh dengan membagi jumlah individu pria yang telah sembuh dari infeksi dengan jumlah individu pria yang terinfeksi. Tingkat pengurangan jumlah individu pria yang terinfeksi dilambangkan dengan $a_{1}$. Sedangkan tingkat pengurangan jumlah individu wanita yang terinfeksi diperoleh dengan membagi jumlah individu wanita yang telah sembuh dari infeksi dengan jumlah individu wanita yang terinfeksi. Tingkat pengurangan jumlah individu wanita yang terinfeksi dilambangkan dengan $a_{2}$.

4. Tingkat penambahan jumlah individu pria yang terinfeksi diperoleh dengan membagi jumlah wanita terinfeksi dengan jumlah individu pria yang rentan. Tingkat penambahan jumlah individu pria yang terinfeksi dilambangkan dengan $b_{1}$. Sedangkan tingkat penambahan jumlah individu wanita yang terinfeksi diperoleh dengan membagi jumlah pria yang terinfeksi dengan jumlah wanita yang rentan. Tingkat penambahan jumlah individu wanita yang terinfeksi ini dilambangkan dengan $b_{2}$.

5. Jumlah total pria dan jumlah total wanita dianggap konstan yang masing-masing dilambangkan dengan $C_{1}$ dan $C_{2}$.

Model penyebaran penyakit Gonore ini dapat digambarkan dalam diagram transfer berikut:

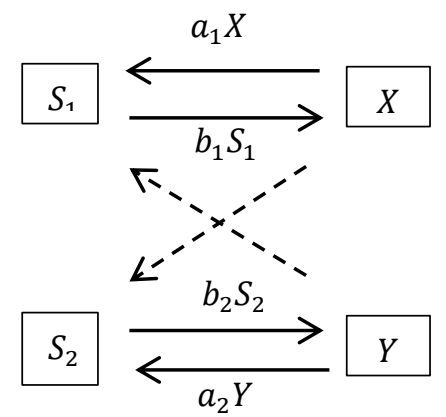

Gambar 1. Diagram transfer model epidemi SI [7]

Pada Gambar 1, panah putus-putus menyatakan interaksi individu antar populasi terinfeksi $X$ dan rentan $S_{2}$ serta terinfeksi $Y$ dan rentan $S_{1}$. Interaksi antara $S_{1}$ dan $S_{2}$ serta interaksi antara $X$ dan $Y$ tidak berpengaruh pada sistem state karena $S_{1}$ dan $S_{2}$ serta $X$ dan $Y$ merupakan individu pada subpopulasi rentan dan individu pada subpopulasi terinfeksi penyakit sehingga interaksi $S_{1}$ dan $S_{2}$ serta $X$ dan $Y$ tidak menyebabkan penyebaran penyakit Gonore. 
Model matematika penyebaran penyakit menular seksual Gonore adalah sebagai berikut [7]:

$$
\begin{aligned}
& \frac{d S_{1}}{d t}=-b_{1} S_{1}+a_{1} X \\
& \frac{d S_{2}}{d t}=-b_{2} S_{2}+a_{2} Y
\end{aligned}
$$

atau

$$
\begin{aligned}
& \frac{d X}{d t}=-a_{1} X+b_{1} S_{1} Y \\
& \frac{d Y}{d t}=-a_{2} Y+b_{2} S_{2} X
\end{aligned}
$$

dengan

$X \quad$ : Jumlah individu pria terinfeksi penyakit Gonore

$Y \quad$ : Jumlah individu wanita terinfeksi penyakit Gonore

$S_{1} \quad$ : Jumlah individu pria yang rentan

$S_{2} \quad$ : Jumlah individu wanita yang rentan

$C_{1} \quad$ : Jumlah total pria

$C_{2} \quad:$ Jumlah total wanita

$t \quad:$ Waktu

$a_{1} \quad$ : Tingkat pengurangan jumlah individu pria yang terinfeksi

$a_{2} \quad$ : Tingkat pengurangan jumlah individu wanita yang terinfeksi

$b_{1} \quad$ : Tingkat penambahan jumlah individu pria yang terinfeksi

$b_{2} \quad$ : Tingkat penambahan jumlah individu wanita yang terinfeksi.

Persamaan (1) merupakan jumlah individu pada subpopulasi rentan pria pada saat $t$ yang akan berkurang karena adanya individu rentan pria yang terinfeksi penyakit Gonore sehingga individu tersebut masuk kedalam subpopulasi terinfeksi pria dan jumlah individu pada subpopulasi rentan pria akan bertambah karena individu pada subpopulasi terinfeksi pria yang sembuh dari penyakit Gonore.

Persamaan (2) merupakan jumlah individu pada subpopulasi rentan wanita pada saat $t$ yang akan berkurang karena adanya individu rentan wanita yang terinfeksi penyakit Gonore sehingga individu tersebut masuk kedalam subpopulasi terinfeksi wanita dan jumlah individu pada subpopulasi rentan wanita akan bertambah karena individu pada subpopulasi terinfeksi wanita yang sembuh dari penyakit Gonore.

Persamaan (3) merupakan jumlah individu pada subpopulasi terifeksi pria pada saat $t$ yang akan berkurang karena adanya kesembuhan pada individu terinfeksi pria sehingga individu tersebut masuk ke dalam subpopulasi rentan pria dan jumlah individu pada subpopulasi terifeksi pria akan bertambah karena adanya interaksi antara individu pada subpopulasi rentan pria dan individu pada subpopulasi rentan wanita.

Persamaan (4) merupakan jumlah individu pada subpopulasi terifeksi wanita pada saat $t$ yang akan berkurang karena adanya kesembuhan pada individu terinfeksi wanita sehingga individu tersebut masuk kedalam subpopulasi rentan wanita dan jumlah individu pada subpopulasi terifeksi wanita akan bertambah karena adanya interaksi antara individu pada subpopulasi rentan wanita dan individu pada subpopulasi rentan pria.

Analisis terhadap model penyebaran penyakit menular seksual Gonore dilakukan melalui Persamaan (3) dan (4). Diasumsikan jumlah populasi pria adalah konstan dan dilambangkan dengan $C_{1}$, dan jumlah populasi wanita konstan dan dilambangkan dengan $C_{2}$, maka jumlah populasi pria dan wanita dapat dituliskan sebagai berikut:

$$
\begin{aligned}
& C_{1}=S_{1}+X \\
& C_{2}=S_{2}+Y
\end{aligned}
$$


sehingga jumlah populasi rentan pria dan wanita dapat dituliskan sebagai berikut:

$$
\begin{gathered}
S_{1}=C_{1}-X \\
S_{2}=C_{2}-Y .
\end{gathered}
$$

Dengan mensubsitusikan Persamaan (5) dan (6) ke Persamaan (3) dan (4), sehingga dapat dituliskan kembali sebagai berikut:

$$
\begin{aligned}
& \frac{d X}{d t}=-a_{1} X+b_{1}\left(C_{1}-X\right) Y \\
& \frac{d Y}{d t}=-a_{2} Y+b_{2}\left(C_{2}-Y\right) X
\end{aligned}
$$

\section{PRINSIP MINIMUM PONTRYAGIN}

Prinsip Minimum Pontryagin merupakan suatu penyelesaian suatu kondisi kontrol optimal sehingga sesuai dengan fungsi tujuan. Pada umumnya, masalah kontrol optimal dalam bentuk model matematika diformulasikan dengan tujuan mencari kontrol $u$ yang mengoptimalkan fungsi tujuan yaitu:

$$
J=S(x, t)+\int_{t_{0}}^{t_{f}} V(x, u, t) d t
$$

dengan persamaan state yang dinyatakan:

$$
\dot{x}=f(x, u, t)
$$

dan kondisi batas

$$
x\left(t_{0}\right)=x_{0}, x\left(t_{f}\right)=x_{f} .
$$

Langkah-langkah penyelesaian kontrol optimal yang diformulasikan oleh Persamaan (8) sampai dengan Persamaan (9) dan dengan fungsi tujuan pada Persamaan (7) adalah sebagai berikut [6]:

1. Membentuk suatu fungsi Hamiltonian

$$
H(x, u, t, \lambda)=V(x, u, t)+\sum_{i=1}^{n} \lambda_{i}(t) f_{i}(x, u, t),
$$

dengan $V$ adalah fungsi tujuan, $\lambda$ adalah variabel costate, dan $f$ merupakan persamaan state [8].

2. Meminimumkan fungsi Hamiltonian terhadap variabel kontrol $u$, dengan cara: $\frac{\partial H}{\partial u}=0$,

sehingga didapatlah kontrol $u$ yang optimal $\left(u^{*}\right), u^{*}=h\left(x^{*}, \lambda^{*}, t\right)$.

3. Gunakan hasil dari langkah 2 untuk mendapatkan fungsi Hamiltonian baru yang optimal, $H^{*}$ sebagai berikut:

$H^{*}\left(x^{*}, h\left(x^{*}, \lambda^{*}, t\right), t, \lambda^{*}\right)=H^{*}\left(x^{*}, \lambda^{*}, t\right)$.

4. Menyelesaikan persamaan state, yaitu:

$\dot{x}=\frac{\partial H}{\partial \lambda}$

dan persamaan costate, yaitu:

$\dot{\lambda}=-\frac{\partial H}{\partial x}$

dengan kondisi awal $x_{0}$ dan keadaan akhir yang disebut kondisi transversality, yaitu:

$\left[H^{*}+\frac{\partial S}{\partial t}\right]_{t_{f}} \delta t_{f}+\left[\frac{\partial S}{\partial x}-\lambda^{*}\right]_{t_{f}} \delta x_{f}=0$,

dengan $S$ adalah bentuk Mayer dari fungsi tujuan $J, H$ merupakan fungsi Hamiltonian, $\delta$ menujukkan variasi, dan tanda * menyatakan keadaan saat variabel dalam keadaan optimal.

5. Substitusikan $x$ dan $\lambda$ yang diperoleh dari langkah 4 kedalam persamaan $u^{*}$ sehingga didapat kendali yang optimal. 


\section{METODE RUNGE KUTTA ORDE 4}

Pada penelitian ini, digunakan metode Runge Kutta Orde 4 untuk menyelesaikan persamaan state (10) dan persamaan costate (11) yang merupakan persamaan diferensial nonlinear yang sulit diselesaikan secara analitik. Pada persamaan state diketahui nilai awal sehingga diselesaikan dengan menggunakan Runge Kutta Orde 4 skema maju. Sedangkan untuk persamaan costate diselesaikan dengan menggunakan Runge Kutta Orde 4 skema mundur karena nilai akhir costate diketahui [9].

Diberikan fungsi dari persamaan diferensial berikut ini:

$y^{\prime}=f(x, y)$.

Metode Runge Kutta Orde 4 memiliki bentuk [10]:

$y_{n+1}=y_{n}+\frac{1}{6}\left(k_{1}+2 k_{2}+2 k_{3}+k_{4}\right)$,

dengan:

$k_{1}=h f\left(x_{n}, y_{n}\right)$,

$k_{2}=h f\left(x_{n}+\frac{1}{2} h, y_{n}+\frac{1}{2} k_{1}\right)$,

$k_{3}=h f\left(x_{n}+\frac{1}{2} h, y_{n}+\frac{1}{2} k_{2}\right)$,

$k_{4}=h f\left(x_{n}+h, y_{n}+k_{3} h\right)$,

$h=\Delta x$.

\section{MODEL MATEMATIKA PENYEBARAN PENYAKIT MENULAR SEKSUAL GONORE DENGAN PEMBERIAN KONTROL}

Permasalahan kontrol optimal pada model penyebaran penyakit menular seksual Gonore yaitu untuk meminimumkan jumlah individu yang terinfeksi penyakit dengan melakukan pengobatan dengan menggunakan antibiotik. Pada model penyebaran penyakit menular seksual Gonore akan diberikan variabel kontrol $u$ berupa antibiotik pada subpopulasi terinfeksi. Kontrol $u$ diberikan untuk memimumkan jumlah individu yang terinfeksi penyakit menular seksual Gonore. Model penyebaran penyakit menular seksual Gonore dengan kontrol $u$ adalah sebagai berikut:

$$
\begin{aligned}
& \frac{d X}{d t}=-a_{1} X+b_{1}(1-u)\left(C_{1}-X\right) Y, \\
& \frac{d Y}{d t}=-a_{2} Y+b_{2}(1-u)\left(C_{2}-Y\right) X,
\end{aligned}
$$

dengan fungsi tujuan:

$$
J=\int_{t_{0}}^{t_{1}} A_{1} X+A_{2} Y+\frac{1}{2} u^{2} d t
$$

Diasumsikan bahwa nilai awal seluruh populasi bernilai positif $X(0)=X_{0} \geq 0, Y(0)=Y_{0} \geq 0$ dan kondisi batas $t_{0}<t<t_{f}, 0 \leq u(t) \leq 0.9$. Batas tersebut menandakan bahwa waktu awal yang diberi pengontrol sampai waktu akhir pengontrol $t_{f}, u$ merupakan persentase jumlah individu yang terinfeksi yang diberikan pengobatan berupa antibiotik, dan $A_{1}, A_{2}$ adalah konstanta positif untuk menjaga ukuran $X$ dan $Y$.

\section{PENYELESAIAN KONTROL OPTIMAL PADA MODEL PENYEBARAN PENYAKIT MENULAR SEKSUAL GONORE}

Adapun langkah-langkah penyelesaian kontrol optimal penyebaran penyakit menular seksual Gonore menggunakan Prinsip Minimum Pontryagin adalah sebagai berikut:

1. Membentuk suatu fungsi Hamiltonian

$$
\begin{aligned}
H(x, u, t, \lambda)= & V(x, u, t)+\sum_{i=1}^{n} \lambda_{i}(t) f_{i}(x, u, t) \\
= & A_{1} X+A_{2} Y+\frac{1}{2} u^{2}+\lambda_{1}\left(-a_{1} X+b_{1}(1-u)\left(C_{1}-X\right) Y\right)+\lambda_{2}\left(-a_{2} Y+\right. \\
& \left.b_{2}(1-u)\left(C_{2}-Y\right) X\right) .
\end{aligned}
$$


2. Selanjutnya, meminimumkan fungsi Hamiltonian terhadap variabel kontrol $u$, dengan cara:

$$
\begin{aligned}
\frac{\partial H}{\partial u} & =0 \\
u & =\lambda_{1} b_{1}\left(C_{1} Y-X Y\right)+\lambda_{2} b_{2}\left(C_{2} X-X Y\right) .
\end{aligned}
$$

Karena $0 \leq u \leq 0.9$, sehingga diperoleh beberapa kemungkinan yaitu:

$$
u^{*}=\left\{\begin{array}{cr}
u & \text { jika } 0<u<0.9 \\
0 & \text { jika } u \leq 0 \\
0.9 & \text { jika } u \geq 0.9
\end{array}\right.
$$

Nilai kontrol yang optimal pada Persamaan (12) dapat ditulis dalam bentuk:

$$
u^{*}=\operatorname{maks}\{\min (u, 0.9), 0\} \text {. }
$$

3. Gunakan hasil dari langkah 2 untuk mendapatkan fungsi Hamiltonian baru yang optimal, $H^{*}$ sebagai berikut:

$H^{*}\left(x^{*}, h\left(x^{*}, \lambda^{*}, t\right), t, \lambda^{*}\right)=H^{*}\left(x^{*}, \lambda^{*}, t\right)$.

4. Menyelesaikan persamaan state, yaitu:

$$
\begin{aligned}
\dot{X} & =\frac{\partial H}{\partial \lambda_{1}} \\
& =-a_{1} X+b_{1}(1-u)\left(C_{1}-X\right) Y, \\
\dot{Y} & =\frac{\partial H}{\partial \lambda_{2}} \\
& =-a_{2} Y+b_{2}(1-u)\left(C_{2}-Y\right) X,
\end{aligned}
$$

dengan kondisi awal $X(0)=X_{0} \geq 0$ dan $Y(0)=Y_{0} \geq 0$

Selanjutnya menyelesaikan persamaan costate, yaitu:

$$
\begin{aligned}
\dot{\lambda_{1}} & =-\frac{\partial H}{\partial X} \\
& =\lambda_{1} a_{1}+\lambda_{1} b_{1} Y-\lambda_{1} b_{1} u Y-A_{1}, \\
\dot{\lambda_{2}} & =-\frac{\partial H}{\partial Y} \\
& =\lambda_{2} a_{2}+\lambda_{2} b_{2} X-\lambda_{2} b_{2} u X-A_{2},
\end{aligned}
$$

dengan kondisi batas $\lambda_{1}=0$ dan $\lambda_{2}=0$

5. Substitusikan hasil yang diperoleh dari langkah 4 ke dalam Persamaan (11) sehingga didapat kendali yang optimal, yaitu sebagai berikut:

$$
\begin{aligned}
\dot{X} & =\frac{\partial H}{\partial \lambda_{1}} \\
& =-a_{1} X+b_{1}\left(1-u^{*}\right)\left(C_{1}-X\right) Y, \\
\dot{Y} & =\frac{\partial H}{\partial \lambda_{2}} \\
& =-a_{2} Y+b_{2}\left(1-u^{*}\right)\left(C_{2}-Y\right) X, \\
\dot{\lambda_{1}} & =-\frac{\partial H}{\partial X} \\
& =\lambda_{1} a_{1}+\lambda_{1} b_{1} Y-\lambda_{1} b_{1} u^{*} Y-A_{1}, \\
\dot{\lambda_{2}} & =-\frac{\partial H}{\partial Y} \\
& =\lambda_{2} a_{2}+\lambda_{2} b_{2} X-\lambda_{2} b_{2} u X-A_{2} .
\end{aligned}
$$

\section{SIMULASI NUMERIK}

Persamaan state dan costate pada Persamaan (12) sampai dengan Persamaan (15) merupakan persamaan nonlinear sehingga sulit untuk diselesaikan secara analitik. Oleh karena itu, persamaan state dan costate diselesaikan secara numerik dengan menggunakan metode Runge Kutta orde 4 karena memiliki ketelitian yang cukup tinggi. 
Model penyebaran penyakit menular seksual Gonore dengan menggunakan kontrol pengobatan berupa antibiotik disimulasikan pada saat populasi awal $\left(X_{0}, Y_{0}\right)$ adalah $(20,35)$ dengan jumlah total pria dan wanita berturut-turut adalah 150 dan 250, $0 \leq u \leq 0.9$, dan batas waktu pengontrolan adalah 0 sampai 100 bulan. Kemudian, diberikan nilai parameter pada Tabel 1 [7]:

Tabel 1. Nilai Parameter Penyebaran Penyakit Gonore

\begin{tabular}{cc}
\hline Parameter & Nilai \\
\hline$a_{1}$ & 1 \\
$a_{2}$ & 1 \\
$b_{1}$ & 0.006 \\
$b_{2}$ & 0.004 \\
$A_{1}, A_{2}$ & 1 \\
\hline
\end{tabular}

Nilai parameter yang terdapat pada Tabel 1 tersebut kemudian disubstitusikan ke dalam Persamaan (12) sampai dengan Persamaan (15) untuk selanjutnya disimulasikan secara numerik. Berdasarkan hasil simulasi numerik yang telah dilakukan, didapat grafik sebagai berikut

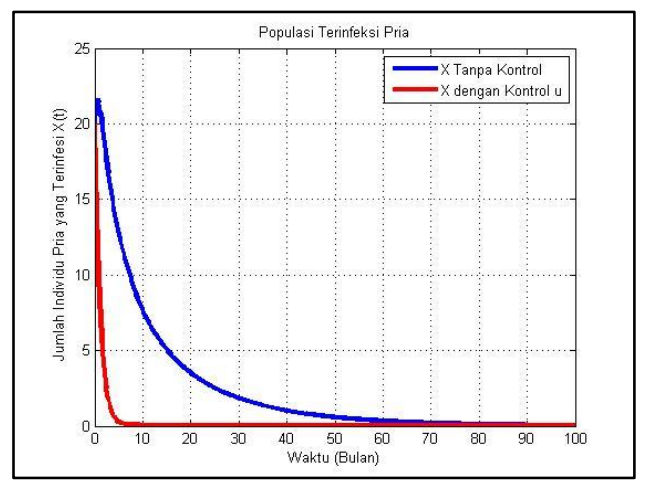

Gambar 2. Grafik jumlah individu pada subpopulasi terinfeksi pria dengan dan tanpa kontrol

Berdasarkan Gambar 2, terlihat bahwa jumlah individu pada subpopulasi terinfeksi pria tanpa kontrol pengobatan mengalami penurunan lebih lambat dibandingkan dengan penurunan jumlah individu pada subpopulasi terinfeksi pria dengan pemberian kontrol. Jumlah individu terinfeksi pria dengan penambahan kontrol pengobatan mengalami penurunan secara signifikan pada awal periode pemberian kontrol pengobatan berupa antibiotik yaitu pada saat $t=0$ dan terus mengalami penurunan hingga akhirnya konstan pada sekitar bulan ke-10 terus hingga bulan ke-100 yang artinya sudah tidak ada individu pria yang terinfeksi penyakit menular seksual Gonore.

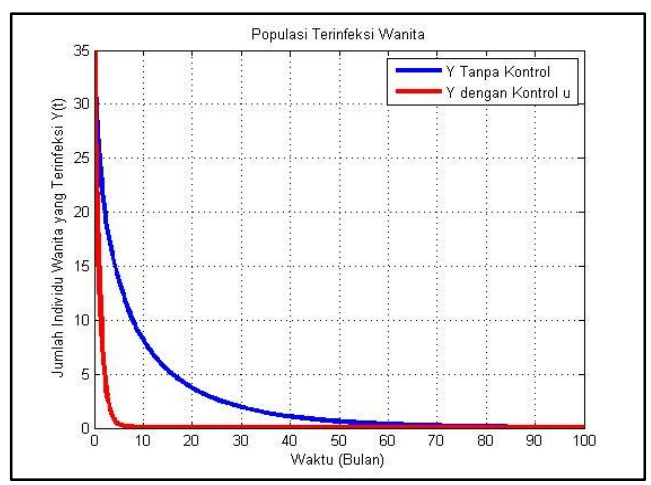

Gambar 3. Grafik jumlah individu pada subpopulasi terinfeksi wanita dengan dan tanpa kontrol 
Berdasarkan Gambar 3, terlihat bahwa jumlah individu pada subpopulasi terinfeksi wanita tanpa kontrol pengobatan mengalami penurunan lebih lambat dibandingkan dengan penurunan jumlah individu pada subpopulasi terinfeksi wanita dengan pemberian kontrol. Jumlah individu terinfeksi wanita dengan penambahan kontrol pengobatan mengalami penurunan secara signifikan pada awal periode pemberian kontrol pengobatan berupa antibiotik yaitu pada saat $t=0$ dan terus mengalami penurunan hingga akhirnya konstan pada sekitar bulan ke-10 terus hingga bulan ke-100 yang artinya sudah tidak ada individu pria yang terinfeksi penyakit menular seksual Gonore.

Selanjutnya, disajikan grafik penyebaran penyakit Gonore pada subpopulasi rentan pria dan rentan wanita, sebagai berikut:

Gambar 4. Grafik jumlah ida subpopulasi rentan pria an dan tanpa kontrol

Gambar 4 merupakan diketahui bahwa jumlah rentan pria tanpa kontrol kenaikan lebih lambat kenaikan jumlah individu kontrol pada subpopulasi

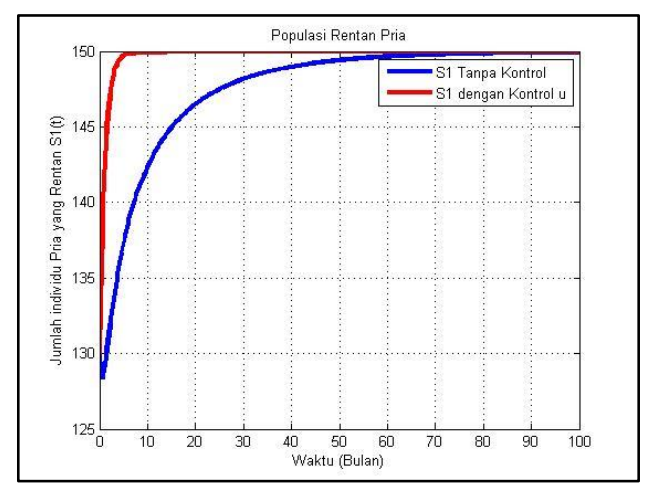

akibat dari Gambar 2 yang individu pada subpopulasi pengobatan mengalami dibandingkan dengan rentan pria dengan pemberian terinfeksi pria. Jumlah individu rentan pria dengan adanya penambahan kontrol pengobatan menyebabkan jumlah individu rentan pria mengalami kenaikan secara signifikan pada awal periode pemberian kontrol pengobatan yaitu pada $t=0$ dan terus mengalami kenaikan hingga akhirnya konstan pada sekitar bulan ke-12 terus hingga bulan ke-100. Hal ini terjadi karena adanya perpindahan individu dari subpopulasi terinfeksi pria ke subpopulasi rentan pria karena adanya proses penyembuhan.

Gambar 5. Grafik jumlah da subpopulasi rentan wanita gan dan tanpa kontrol

Gambar 5 merupakan diketahui bahwa jumlah rentan wanita tanpa kontrol kenaikan lebih lambat kenaikan jumlah individu pemberian kontrol pada

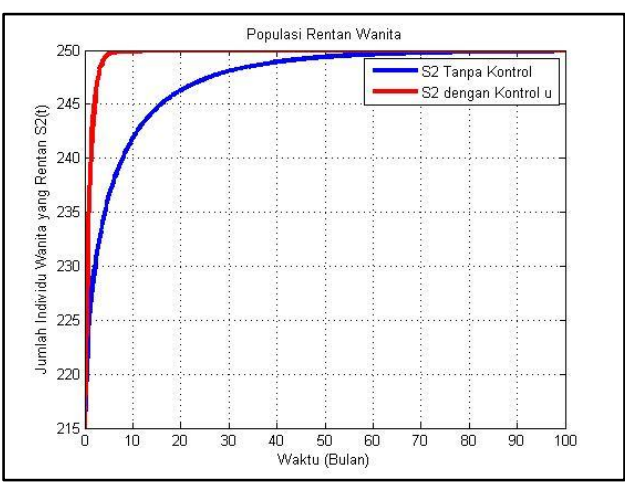

akibat dari Gambar 3 yang individu pada subpopulasi pengobatan mengalami dibandingkan dengan rentan wanita dengan subpopulasi terinfeksi wanita. Jumlah individu rentan wanita dengan adanya penambahan kontrol pengobatan menyebabkan jumlah individu rentan wanita mengalami kenaikan secara signifikan pada awal periode pemberian kontrol pengobatan yaitu pada $t=0$ dan terus mengalami kenaikan hingga akhirnya konstan pada sekitar bulan ke-12 terus hingga bulan ke-100. Hal ini terjadi karena adanya perpindahan individu dari subpopulasi

terinfeksi wanita ke subpopulasi rentan wanita karena adanya proses penyembuhan.

Selanjutnya disajikan grafik persentase pemberian kontrol pengobatan berupa antibiotik dan grafik fungsi tujuan:

Gambar 6. Grafik Kontrol $u$ Berdasarkan Gambar 6, periode pengendalian, individu terinfeksi adalah selama kurang lebih 5 bulan, menurun dan berhenti pada pemberian pengobatan ini

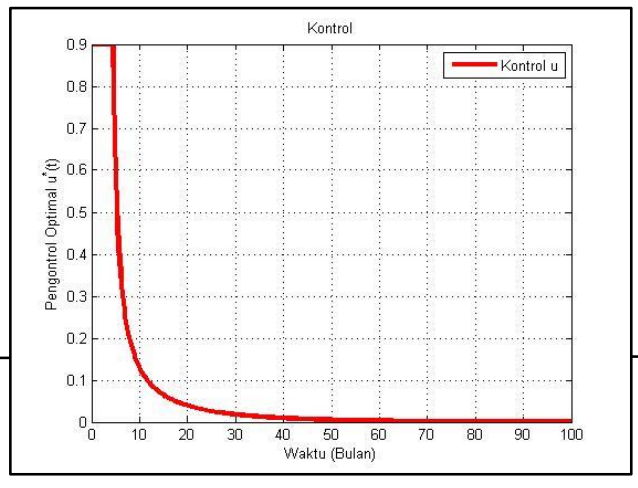

terlihat bahwa pada awal pemberian pengobatan pada maksimal yakni 0.9 stabil kemudian bergerak bulan ke-62. Penurunan disebabkan karena jumlah 
individu pada subpopulasi terinfeksi semakin berkurang karena mengalami kesembuhan. Hasil dari penerapan kontrol $u$ atau pemberian pengobatan berupa antibiotik yang dilakukan dalam mengendalikan populasi yang terinfeksi memberikan suatu hasil yang optimal dengan fungsi tujuan yang minimum.

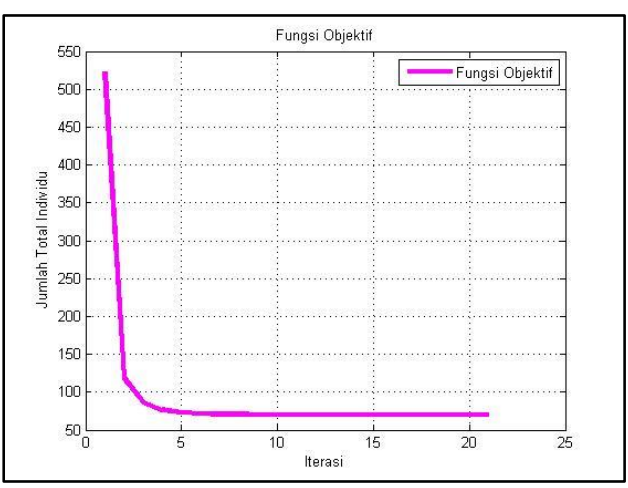

Gambar 7. Grafik Fungsi Tujuan

Berdasarkan Gambar 7, terlihat bahwa pemberian kontrol pengobatan menggunakan antibiotik $u$ menyebabkan fungsi tujuan yang pada awalnya berjumlah 525 berkurang dan bernilai minimum sebesar kurang lebih 65 pada iterasi ke-21. Hal ini menyatakan bahwa pemberian kontrol $u$ berupa pengobatan dengan antibiotik meminimumkan jumlah individu pada subpopulasi terinfeksi.

\section{PENUTUP}

Berdasarkan pembahasan yang telah dipaparkan, maka dapat ditarik kesimpulan, yaitu:

1. Model penyebaran penyakit menular seksual Gonore dengan menggunakan kontrol $u$ adalah:

$$
\begin{aligned}
& \frac{d X}{d t}=-a_{1} X+b_{1}(1-u)\left(C_{1}-X\right) Y, \\
& \frac{d Y}{d t}=-a_{2} Y+b_{2}(1-u)\left(C_{2}-Y\right) X .
\end{aligned}
$$

2. Penyelesaian kontrol optimal model penyebaran penyakit menular seksual Gonore diselesaikan menggunakan Prinsip Minimum Pontryagin sehingga diperoleh kontrol $u^{*}$ berupa pengobatan menggunakan antibiotik yang optimal yaitu:

$$
u^{*}=\operatorname{maks}\{\min (u, 0.9), 0\} .
$$

Berdasarkan hasil simulasi numerik, pemberian kontrol $u$ berupa pengobatan menggunakan antibiotik menunjukkan keefektifan pada pengendalian penyebaran penyakit menular seksual Gonore sehingga penyebaran penyakit dapat ditekan. Hal tersebut berakibat berkurangnya jumlah individu pada subpopulasi terinfeksi.

\section{DAFTAR PUSTAKA}

[1] Kemenkes RI. Pedoman Nasional Penanganan Infeksi Menular Seksual. 2016.

[2] WHO. Guidelines for the Management of Sexually Transmitted Infection. 2018. [Serial Online], http://apps.who.int/iris/bitstream/10665/42782/1/9241546263eng.pdf?ua=1 (29 Maret 2019)

[3] Martiastutik D. Buku Ajar Infeksi Menular Seksual. Surabaya: Airlangga University Pres; 2008.

[4] Ikhtisholiyah, 2011, Analisis Stabilitas dan Optimal Kontrol pada Model Epidemi Tipe SIR dengan Vaksinasi (Serial Online), http://digilib.its.ac.id/public/ITS-Undergraduate-17439-Paper1377307.pdf (10 Januari 2019).

[5] Subiono. Sistem Linear dan Kontrol Optimal.Surabaya. ITS. 2013.

[6] Naidu DS. Optimal Control System. New York: CRC Pres; 2002.

[7] Wahyuni T, Kusumastuti N, Prihandono B. Pemodelan Matematika dan Analisis Stabilitas dari Penularan Penyakit Gonore. Bimaster: 2015; 4:47-56.

[8] Chiang AC. Fundamental Methode of Mathematical Econimics Fourth Edition. New York: the McGrew-Hill; 2005. 
[9] Saraswati P. Analisis dan Kontrol Optimal Sistem Gerak Satelit Menggunakan Prinsip Minimum Pontryagin. Jurnal Sains dan Seni ITS. 2017; 6(2): 2337-3520.

[10] Munir R. Metode Numerik. Bandung: Informatika; 2012

LOVI DWI PURNAMASARI

MARIATUL KIFTIAH

YUDHI
: Jurusan Matematika FMIPA Untan, Pontianak, lovipopi96@gmail.com

: Jurusan Matematika FMIPA Untan, Pontianak, kiftiahmariatul@math.untan.ac.id

: Jurusan Matematika FMIPA Untan, Pontianak, yudhi@math.untan.ac.id 